\title{
The ichthyoneuston of Galway Bay (west of Ireland). II. Food of post-larval and juvenile neustonic and pseudoneustonic fish
}

\author{
Oliver Tully*, Padraic Ó Céidigh \\ Department of Zoology, University College, Galway, Ireland
}

\begin{abstract}
Stomach contents of 5 species of neustonic (Ciliata septentrionalis, Ciliata mustela, Gaidropsaurus mediterraneus, Rhinonemus cimbrius, Scophthalmus maximus) and 4 species of pseudoneustonic (Pollachius pollachius, Pollachius virens, Merlangius merlangus, Cyclopterus lumpus) post-larval and juvenile fish, caught in the neustal and the immediate sub-surface layer, were examined to compare diets and food consumption. Fish length ranged from 5 to $39 \mathrm{~mm}$. The diets of Ciliata spp. were dominated by fish eggs and calanoid copepods. $G$. mediterraneus and $R$. cimbrius ate mainly copepods and Cladocera. Oikopleura spp., copepods and Podon spp. dominated in S. maximus. In the pseudoneustonic Pollachius spp., Acartia spp. and Calanus spp. were most important while $M$. merlangus preyed almost totally on copepods. C. lumpus, which associated with driftweed, specialised on harpacticoid copepods and crab megalopae. Dietary differences among species $5 \mathrm{~mm}$ length groups were investigated by step-wise discriminant analysis. The analysis isolated 17 diet categories which were significant in discriminating the diets of $5 \mathrm{~mm}$ length groups of 5 species (C. septentrionalis, $C$. mustela, $P$. pollachius, $P$. virens, $M$. merlangus) caught mainly during May and June. Ciliata groups were distinct from those of other species and their diets changed gradually as fish increased in length. Fish eggs were less important in larger fish which preyed more on fish larvae, crab megalopae and harpacticoid copepods. Five diet categories were significant in discriminating the diets of $5 \mathrm{~mm}$ length groups of species caught mainly during autumn (G. mediterraneus, $R$. cimbrius, S. maximus, C. lumpus). The diets of $S$. maximus and $C$. lumpus changed abruptly when fish reached $20 \mathrm{~mm}$ in length. $C$. lumpus switched from harpacticoid copepods to crab megalopae and $S$. maximus switched from Podon spp. to fish larvae and Oikopleura spp. Podon spp. were important in larger size groups of G. mediterraneus and $R$. cimbrius. Discriminant analysis did not find significant differences between the diets of smaller length groups of these 2 species. Diel variation in stomach fullness of $C$. mustela and $G$. mediterraneus showed that feeding occurred only during daylight. In all species except $G$. mediterraneus and $S$. maximus larger fish ate a greater number of prey than smaller fish. C. mustela over $25 \mathrm{~mm}, P$. pollachius and $M$. merlangus over $15 \mathrm{~mm}$ and $C$. lumpus and $S$. maximus over $20 \mathrm{~mm}$ also had fuller stomachs than smaller fish. Stomach fullness was higher in neustonic than in pseudoneustonic species. Because of this, it is suggested that feeding conditions at the surface are unique and that neustonic species have adaptations that enable them to feed more successfully in this environment.
\end{abstract}

\section{INTRODUCTION}

Conditions at the sea surface and the amount of food available there to predatory fish varies with geographic location. Zaitsev (1970) observed that the neustal of the Black Sea was important in the early ontogeny of many species of fish. Hartman (1970) and John (1973) found a scarcity of food by day in the neustal of the subtropical North East Atlantic where only areas of upwelling

\footnotetext{
- Present address: Department of Zoology, Trinity College, Dublin, Ireland
}

supported high densities of neustonic fish such as Belone belone (L.). In coastal temperate regions neustonic communities are less well developed, the number of neustonic species is lower than in tropical waters and the plankton communities in the neustal by day are largely similar to those of subsurface layers (Hempel \& Weikert 1972). The diets, food availability to and food consumption of neustonic fish species in the such areas may therefore be largely similar to those of species of similar size and morphology which occur at the surface but live predominantly in deeper water (pseudoneustonic species; Hempel \& Weikert 1972). On the other 
hand if they are different it may infer that feeding conditions at the surface are unique and that neustonic species have adaptations that enable them to feed more successfully in the neustal than pseudoneustonic species. Even in areas where neustonic communities are poorly developed feeding conditions for fish at the sea/air contact zone may differ from those in deeper water due to a number of factors. Organic matter in the form of eolian and terrigenic material and also 'antirain' of dead plankters, moulted casts and exometabolites from the water column (Zaitsev 1970) and flotsam and its associated fauna (Tully \& O Céidigh 1986a) accumulate at the surface. Migration of planktonic and benthic invertebrates to the surface at night leads to considerable changes in the density and species composition of possible prey items in the neustal at this time (Champalbert \& Macquart-Moulin 1970, Champalbert 1971a, b, Macquart-Moulin 1984, Tully \& Ó Céidigh 1986b, 1987). Light intensity at the surface is higher for longer periods than in deeper water. This may extend the time during which visual predators can feed, and such predators may also be able to feed by moonlight. Also, since neustonic species live essentially in a 2-dimensional environment (ignoring depth), escape options for prey species are reduced (Zaitsev $1970)$.

The present work describes the diets and feeding intensity of 5 neustonic and 4 pseudoneustonic species of post-larval and juvenile fish captured in the neustal and in immediate subsurface water of Galway Bay, a coastal temperate region of high primary productivity. Interspecific differences in diet and food consumption and differences among species $5 \mathrm{~mm}$ size classes are compared and related to individual species morphology and behaviour.

\section{STUDY AREA AND METHODS}

Galway Bay. All fish were sorted from neuston samples taken in Galway Bay (Fig. 1) during daylight hours from June 1983 to September 1984, during the night from May to September 1984 and over two $24 \mathrm{~h}$ periods during September 1984 and August 1985. A 2-stage neuston net sampling the 0 to $100 \mathrm{~mm}$ and 120 to $480 \mathrm{~mm}$ surface microlayers was employed at all stations. Sample volume was ca 100 and $360 \mathrm{~m}^{3}$ for the upper and lower nets respectively.

The hydrographic characteristics of Galway Bay were described by Berthois et al. (1971) and Booth (1975). Briefly, the inner bay (Stns 1 to 3; Fig. 1) is largely estuarine and salinities were reduced to $16 \%$ at Stn 1 during February. Salinities in the outer bay remained above $34 \%$ throughout the sampling period. Surface temperatures varied from $6^{\circ} \mathrm{C}$ in January to

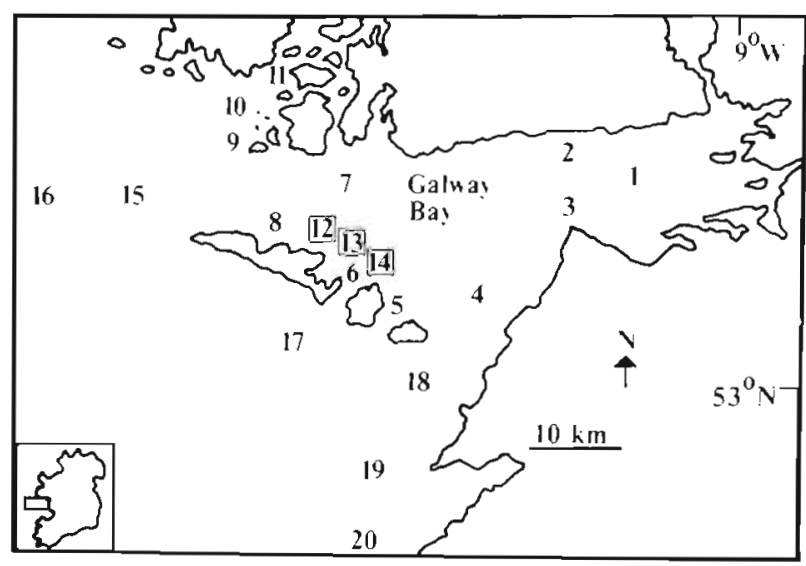

Fig. 1. Galway Bay showing day and night $(\square)$ locations where neuston samples were taken

$18.3^{\circ} \mathrm{C}$ in August. Intrusions of oceanic water into the bay are known to occur frequently (Booth 1975).

Fish distribution and behaviour. Diverse larval and juvenile fish species assemblages, comprising 82 species, were recorded in the surface $0.5 \mathrm{~m}$ of water (Tully \& $O$ Céidigh 1988). Only 8 of these species however, were neustonic at any stage of their life cycle. The diets of 5 of these are given here (Table 1). Four pseudoneustonic species caught in the surface $0.5 \mathrm{~m}$ of water, which were common and of comparable size range to the neustonic species, were also selected for dietary analysis (Table 1). The 9 species of fish are separable into 2 groups based on their temporal distribution. One group of 5 species (Table 1) occurred during May and June (spring group) while the remaining 4 species occurred predominantly during August and September (autumn group).

Ciliata septentrionalis, Ciliata mustela and Ciliata spp. (unidentified fish 10 to $14 \mathrm{~mm}$ in length) were the only abundant neustonic fish species in daylight samples. They occurred, as juveniles, predominantly during May (93 ind. $100 \mathrm{~m}^{-3}$ ) and June (21 ind. $100 \mathrm{~m}^{-3}$ ). Individuals longer than $14 \mathrm{~mm}$ were largely confined to the upper $100 \mathrm{~mm}$ of water. Ciliata spp. occurred at a density of 11.5 ind $100 \mathrm{~m}^{-3}$ in the surface layer in May The pseudoneustonic species Pollachius pollachius (11.5 ind. $100 \mathrm{~m}^{-3}$ in May), Pollachius virens $(0.3 \mathrm{ind}$. $100 \mathrm{~m}^{-3}$ in May) and Merlangius merlangus (2.3 ind. $100 \mathrm{~m}^{-3}$ in May) were evenly distributed in the 2 layers sampled. Gaidropsaurus mediterraneus and Rhinonemus cimbrius were neustonic and occurred mainly during September $1984\left(5.7\right.$ and 1.4 ind. $100 \mathrm{~m}^{-3}$ respectively in the surface layer). Scophthalmus maximus occurred mainly during July and August 1983 in the surface layer $\left(0.8\right.$ ind. $\left.100 \mathrm{~m}^{-3}\right)$. Cyclopterus lumpus was recorded in association with driftweed mainly during May (2.2 ind. $\left.100 \mathrm{~m}^{-3}\right)$ and June $\left(4.0\right.$ ind $100 \mathrm{~m}^{-3}$ ) 
Table 1. Fish species whose diets were studied, the numbers and length range of individuals examined and the months during which they were most abundant in the neustal. Spring (species 1 to 5) and autumn (species 6 to 9) groups are distinguished. - Neustonic species

\begin{tabular}{|c|c|c|c|c|}
\hline Species & Abbrev. & $\begin{array}{l}\text { No. of } \\
\text { fish }\end{array}$ & $\begin{array}{l}\text { Length range } \\
\qquad(\mathrm{mm})\end{array}$ & $\begin{array}{l}\text { Months of } \\
\text { highest density }\end{array}$ \\
\hline - Ciliata septentrionalis Collett & C.s. & 465 & $14-39$ & May, Jun \\
\hline - Ciliata mustela (L.) & C. $m$. & 328 & $14-34$ & May, Jun \\
\hline - Ciliata spp. & C. spp. & 234 & $10-14$ & May \\
\hline Pollachius pollachius (L.) & P. $p$. & 241 & $5-25$ & May, Jun \\
\hline Pollachius virens (L.) & P. $v$ & 39 & $15-25$ & May, Jun \\
\hline Merlangius merlangus (L.) & M. m. & 77 & $5-20$ & May, Jun \\
\hline - Gaidropsaurus mediterraneus (L.) & G. $m$. & 119 & $5-35$ & Jul, Aug \\
\hline - Rhinonemus cimbrius (L.) & R. c. & 27 & $10-25$ & Sep, Nov \\
\hline ' Scophthalmus maximus (L.) & $S . m$ & 25 & $5-25$ & Jul, Aug \\
\hline Cyclopterus lumpus L. & Cy. 1. & 31 & $10-35$ & May-Aug \\
\hline
\end{tabular}

1984 but predominantly during August 1985 (1.0 ind $\left.100 \mathrm{~m}^{-3}\right)$

Species assemblages in the neustal. The species assemblages in the neustal during May and June and therefore the potential prey species available to the spring group of fish were distinct from those available to the autumn group (August and September). The diets of species within but not between groups can therefore be compared. The main species groups in the neustal during daylight hours were largely similar to those in the plankton of the area reported on by $O$ Céidigh (1962) and Fives (1969, 1970, 1971) and few neustonic species were encountered. Fish eggs, larvae of Ammodytidae and low numbers of the neustonic copepod Anomalocera patersoni Templeman predominated in February and March. During April cyprids of Balanus spp. and fish eggs were very abundant and these were succeeded by blooms of Calanus spp., Temora Iongicornis Müller and Acartia spp. In July and August the zoeae and megalopae of portunid and porcellain crabs were abundant. Dense patches of $A$. patersoni were encountered during August 1983 but not during 1984 and Centropages spp. were also common at this time. Benthic peracarideans migrating to the neustal at night were the predominant species at the surface at night during July and August 1984 and were also common in May and September 1984 (Tully \& O Céidigh 1987).

Stomach content analysis. The number of fish of each species examined and their size ranges are given in Table 1 . For the abundant species the stomach contents of up to 10 fish in each $5 \mathrm{~mm}$ length group were identified and counted for each station sampled. This gives a good indication of the diet of individual species or length groups of fish for the whole sampling area. Any between-station variation in diet, which contributes to the overall variation in the diet of length groups of fish, is taken into account when comparing the diets of different length groups of fish by the discriminant analysis used. In less abundant species all available fish were examined. Length groups with less than 5 fish were omitted from all analysis. Prey items were identified to the lowest possible taxonomic level. Unidentified copepods, euphausids and fish were measured and grouped by size. Copepods that could not be measured or identified were counted and copepods that could not be counted were recorded as being present. The numerical importance of each of 57 prey categories is expressed as the percentage composition (the number of items of a particular prey category as a percentage of the total number of prey items) and the spread or distribution of each prey category in the fish population is given by the percentage occurrence or the percentage of fish containing the prey category. Before dissecting the stomach its state of distension or fullness was subjectively assessed. Points on a scale of 0 to 5 were given for a stomach which was empty $(0)$, that had food present (1), that was $1 / 3$ full (2), $2 / 3$ full (3), full (4) and distended (5).

Comparison of the diets of $5 \mathrm{~mm}$ length groups of fish and the prey categories contributing most to group difference was assessed by step-wise discriminant analysis (Jennrich \& Sampson 1981). Only fish with non-empty stomachs were used. The data, counts of individual prey types, was transformed to log (data value +1 ) to comply with conditions of normality before analysis and 54 quantitatively assessed prey categories were used (Table 2). In step-wise discriminant analysis prey categories for which group $(5 \mathrm{~mm}$ length groups of fish) means differ most are entered into the analysis first so that group differences rather than quantitatively important dietary components per se are emphasised. However, because maximum among-group differences are sought by the analysis single discriminating prey categories are likely to be quantitatively important dietary components in at least some groups. The subset 
Table 2. The $\%$ composition ( $\% \mathrm{~N})$ and $\%$ occurrence $(\% \mathrm{O})$ of 57 prey categories in 9 species of fish. Ciliata spp. are either C. mustela or C. septentrionalis 10 to $14 \mathrm{~mm}$ in length. See Table 1 for explanation of species abbreviations. ${ }^{*}<0.5$

\begin{tabular}{|c|c|c|c|c|c|c|c|c|c|c|c|c|c|c|c|c|c|c|c|c|}
\hline Prey categories & \multicolumn{2}{|c|}{$\begin{array}{l}\text { C.s. } \\
\% \mathrm{~N} \% \mathrm{O}\end{array}$} & \multicolumn{2}{|c|}{ C. $m$} & \multicolumn{2}{|c|}{ C. spp. } & \multicolumn{2}{|c|}{ P. $p$} & $\begin{array}{r}P . \\
\% \mathrm{~N}\end{array}$ & $v$ & \multicolumn{2}{|c|}{ M. m } & $\begin{array}{r}G . \\
\% N\end{array}$ & $\begin{array}{l}m \\
\% \mathrm{O}\end{array}$ & $\begin{array}{r}R \\
\% N\end{array}$ & $\%$ & $\begin{aligned} S . I \\
\% N\end{aligned}$ & $\begin{array}{l}m \\
\% \mathrm{O}\end{array}$ & & $\%$ \\
\hline Crustacea & $\cdot$ & 3 & $\cdot$ & 3 & $\cdot$ & 3 & - & - & - & - & - & - & • & 1 & - & - & - & - & $\cdot$ & 3 \\
\hline Porcellana zoea & 2 & 3 & $\cdot$ & 2 & - & - & - & - & - & - & $\cdot$ & 1 & - & - & - & - & - & - & 1 & 5 \\
\hline Natantia, Decapoda & $\cdot$ & 3 & $\cdot$ & 6 & $\cdot$ & $\cdot$ & - & - & - & - & - & - & $\cdot$ & 3 & - & - & - & - & -- & - \\
\hline Crangon zoea & - & - & - & - & - & - & - & - & - & - & 1 & 1. & - & - & - & - & - & - & 1 & 8 \\
\hline Macropipus zoea 5 & $\cdot$ & $\cdot$ & - & - & - & - & - & - & - & - & - & - & - & - & - & - & - & - & - & - \\
\hline zoea 4 & $\cdot$ & $\cdot$ & · & $\cdot$ & - & - & - & - & - & - & - & - & - & - & - & - & - & - & - & - \\
\hline zoea 3 & - & - & $\cdot$ & $\cdot$ & - & - & - & - & - & - & 5 & 4 & - & - & - & - & - & - & $\cdot$ & 5 \\
\hline zoea 2 & $\cdot$ & $\cdot$ & $\cdot$ & 1 & - & - & - & - & - & - & - & - & - & - & - & - & - & - & - & - \\
\hline zoea 1 & 2 & 6 & $\cdot$ & 3 & $\cdot$ & $\cdot$ & $\cdot$ & ' & - & - & 1 & 2 & $\cdot$ & 1 & - & - & - & - & $\cdot$ & 5 \\
\hline megalopa & $\cdot$ & 3 & 1 & 8 & - & - & $\cdot$ & $\cdot$ & - & - & 1 & 2 & $\cdot$ & 2 & - & - & 1 & 13 & 35 & 50 \\
\hline Copepod nauplii & 2 & 1 & - & - & 7 & 3 & - & $\cdot$ & - & - & - & - & - & - & - & - & - & - & - & - \\
\hline Copepods & 2 & 9 & 6 & 15 & 3 & 12 & 1 & 2 & 4 & 9 & 2 & 3 & 2 & 3 & 7 & 11 & 4 & 7 & 4 & 8 \\
\hline Copepods $1.4-1.6 \mathrm{~mm}$ & $\cdot$ & 1 & $\cdot$ & 1 & $\cdot$ & 1 & $\cdot$ & 1 & 2 & 4 & - & - & $\cdot$ & 1 & 1 & 3 & - & - & - & - \\
\hline $1.2-1.4 \mathrm{~mm}$ & 1 & 3 & 1 & 2 & 1 & 2 & $\cdot$ & 1 & - & - & - & - & - & - & - & - & - & - & - & - \\
\hline $1.0-1.2 \mathrm{~mm}$ & 1 & 4 & 3 & 2 & 2 & 4 & 1 & 4 & - & - & 7 & 4 & 1 & 3 & - & - & - & - & - & - \\
\hline $0.8-1.0 \mathrm{~mm}$ & 7 & 6 & 4 & 7 & 6 & 9 & 2 & 9 & 3 & 8 & 14 & 9 & 3 & 4 & 54 & 17 & - & - & - & - \\
\hline $0.6-0.8 \mathrm{~mm}$ & 4 & 3 & 9 & 8 & 11 & 18 & 6 & 14 & 6 & 6 & 13 & 10 & 47 & 17 & 17 & 14 & 18 & 14 & - & - \\
\hline $0.4-0.6 \mathrm{~mm}$ & 4 & 4 & 3 & 4 & 36 & 21 & 3 & 7 & 3 & 4 & 1 & 1 & 11 & 17 & 3 & 25 & 3 & 20 & $\cdot$ & 3 \\
\hline $0.2-0.4 \mathrm{~mm}$ & 4 & 2 & 2 & 1 & 3 & 3 & 1 & 1 & - & - & - & - & 4 & 7 & 1 & 3 & 1 & 7 & $\cdot$ & 3 \\
\hline Corycaeus spp. & - & - & - & - & - & - & 2 & 11 & - & - & - & - & - & - & - & - & - & - & - & - \\
\hline Isias spp. & - & - & 2 & 4 & - & - & - & - & - & - & - & - & 2 & 4 & $\cdot$ & 3 & 3 & 13 & 3 & 5 \\
\hline Calanus $\quad 1.0-1.5 \mathrm{~mm}$ & $\cdot$ & 1 & $\cdot$ & 1 & $\cdot$ & 2 & 1 & 2 & 7 & 13 & 1 & 2 & $\cdot$ & 1 & - & - & - & -- & - & - \\
\hline $1.5-2.0 \mathrm{~mm}$ & 2 & 9 & 3 & 10 & 1 & 5 & 5 & 19 & 22 & 32 & 1 & 14 & $\cdot$ & 2 & - & - & - & - & 5 & 8 \\
\hline $2.0-2.5 \mathrm{~mm}$ & 12 & 36 & 9 & 35 & $\cdot$ & 5 & 8 & 30 & 23 & 43 & 24 & 24 & 1 & 3 & 2 & 8 & - & - & 3 & 13 \\
\hline Centrophages spp. & 2 & 7 & 1 & 9 & 1 & 3 & 5 & 2 & - & - & 1 & 1 & 14 & 23 & 6 & 25 & 5 & 13 & 3 & 16 \\
\hline Temora longicornis & 9 & 5 & 1 & 8 & 2 & 12 & 8 & 6 & 2 & 6 & 3 & 4 & - & - & $\cdot$ & 3 & 3 & 17 & • & 3 \\
\hline Acartia spp. & 8 & 6 & 1 & 2 & 1 & 3 & 43 & 37 & 9 & 13 & 8 & 10 & 1 & 2 & 2 & 8 & 6 & 13 & $\cdot$ & 3 \\
\hline A. patersoni & $\cdot$ & 1 & $\cdot$ & 3 & - & - & - & - & - & - & - & - & $\cdot$ & 3 & - & - & - & - & - & - \\
\hline Metridia spp. & $\cdot$ & 1 & $\cdot$ & 3 & $\cdot$ & 1 & $\cdot$ & $\cdot$ & " & 2 & - & - & - & - & - & - & - & - & $\cdot$ & 3 \\
\hline Pseudocalanus spp. & $\cdot$ & $\cdot$ & - & - & $\cdot$ & 1 & $\cdot$ & $\cdot$ & - & - & - & - & - & - & - & - & - & - & - & - \\
\hline Polychaetes & $\cdot$ & 1 & $\cdot$ & 2 & - & - & - & - & 1 & 2 & - & - & - & - & - & - & - & - & - & - \\
\hline Harpacticoidea & 12 & 5 & 11 & 15 & $\cdot$ & 2 & $\cdot$ & 3 & - & - & 4 & 3 & - & - & - & - & 3 & 10 & 34 & 60 \\
\hline Idotea spp. & - & * & $\cdot$ & $\cdot$ & - & - & - & - & 1 & 2 & - & - & - & - & - & - & - & - & 4 & 24 \\
\hline Hyperia spp. & $\cdot$ & $\cdot$ & $\cdot$ & 1 & - & - & - & - & - & - & - & - & $\cdot$ & 1 & - & - & - & - & - & - \\
\hline Parathemisto spp. & " & 4 & $\cdot$ & 2 & $\cdot$ & $\cdot$ & - & - & - & - & - & - & $\cdot$ & 1 & $\cdot$ & 3 & - & - & - & - \\
\hline Gammaridea & $\cdot$ & $\cdot$ & $\cdot$ & 1 & - & - & - & - & - & - & - & - & $\cdot$ & 2 & - & - & $\cdot$ & 3 & 4 & 21 \\
\hline Oikopleura spp. & - & - & - & - & - & - & - & - & - & - & - & - & - & - & - & - & 17 & 20 & - & - \\
\hline Alga & & $\cdot$ & & $\cdot$ & & $\cdot$ & & $\cdot$ & & - & & 1 & & - & & - & & 3 & & 3 \\
\hline Invertebrate embryos & 3 & 1 & 1 & 2 & - & - & 2 & 9 & 5 & 8 & - & - & - & - & 2 & 3 & 7 & 7 & - & - \\
\hline $\begin{array}{l}\text { Invertebrate eggs } \\
\text { Evadne spp. }\end{array}$ & & 17 & $\cdot$ & $\begin{array}{c}19 \\
1\end{array}$ & - & $\begin{array}{l}47 \\
-\end{array}$ & • & 5 & - & $\begin{array}{l}2 \\
-\end{array}$ & - & - & & $\begin{array}{l}1 \\
5\end{array}$ & - & - & 1 & $\frac{-}{13}$ & 1 & - \\
\hline $\begin{array}{l}\text { Evadne spp. } \\
\text { Podon spp. }\end{array}$ & · & $\cdot$ & 4 & 8 & $\cdot$ & 1 & - & - & - & - & - & - & $\begin{array}{l}1 \\
7\end{array}$ & 13 & 2 & 3 & 23 & 43 & - & - \\
\hline Cladocera & 2 & 4. & 5 & 7 & 6 & 6 & $\cdot$ & 1 & - & - & $\cdot$ & 1 & 1 & 5 & 2 & 14 & - & - & $\cdot$ & 3 \\
\hline Insects & 1 & 3 & $\cdot$ & 1 & - & - & - & - & - & - & - & - & - & - & - & - & - & - & - & - \\
\hline Balanus cyprids & $\cdot$ & $\cdot$ & $\cdot$ & 1 & - & - & $\cdot$ & 2 & - & - & - & - & - & - & - & - & $\cdot$ & 7 & - & - \\
\hline Fish $20-25 \mathrm{~mm}$ & $\cdot$ & 2 & $\cdot$ & 1 & - & - & " & $\cdot$ & - & - & - & - & - & - & - & - & - & - & - & - \\
\hline $15-20 \mathrm{~mm}$ & $\dot{r}$ & 2 & $\cdot$ & 2 & - & - & $\cdot$ & $\cdot$ & - & - & - & - & - & - & - & - & - & - & $\cdot$ & 3 \\
\hline $10-15 \mathrm{~mm}$ & $\cdot$ & 3 & $\cdot$ & 1 & - & - & - & - & - & - & - & - & $\cdot$ & 1 & - & - & 1 & 10 & & - \\
\hline $5-10 \mathrm{~mm}$ & $\cdot$ & 4 & $\cdot$ & 5 & $\cdot$ & $\cdot$ & $\cdot$ & 2 & 1 & 2 & - & - & - & - & - & - & 1 & 7 & - & - \\
\hline Fish eggs & 32 & 50 & 28 & 47 & 17 & 48 & 4 & 20 & 9 & 17 & - & - & $\cdot$ & 2 & 1 & 3 & - & - & - & - \\
\hline Adult euphausids & $\cdot$ & 1 & $\cdot$ & 2 & - & - & - & - & - & - & - & - & - & - & - & - & - & - & - & - \\
\hline Furcilia $4.5-5.0 \mathrm{~mm}$ & $\cdot$ & 2 & $\cdot$ & 2 & - & - & $\cdot$ & $\cdot$ & - & - & - & - & - & - & - & - & - & - & - & - \\
\hline $4.0-4.5 \mathrm{~mm}$ & $\cdot$ & 2 & $\cdot$ & 1 & $\cdot$ & 1 & - & - & - & - & - & - & - & - & - & - & - & - & - & - \\
\hline $3.5-4.0 \mathrm{~mm}$ & $\cdot$ & 2 & $\cdot$ & 1 & $\cdot$ & 1 & - & - & - & - & - & - & - & - & - & - & - & - & - & - \\
\hline $3.0-3.5 \mathrm{~mm}$ & 1 & 8 & 1 & 9 & 1 & 5 & 1 & $\cdot$ & 1 & 4 & - & - & - & - & - & - & - & - & - & - \\
\hline Calyptopids & - & $\cdot$ & & $\cdot$ & & $\cdot$ & - & - & - & - & - & - & - & - & - & - & - & - & - & - \\
\hline Copepods present & & 14 & & 13 & & 7 & & $\cdot$ & & - & & 3 & & 17 & & 6 & & 3 & & - \\
\hline
\end{tabular}


of prey categories isolated by the analysis will be the categories that best describe quantitative dietary differences among all groups. Differences in stomach fullness (the amount of food consumed in proportion to fish length) and the log of the number of prey eaten among $5 \mathrm{~mm}$ length groups of individual species were assessed by analysing variance among groups ( $F$-tests) and by pair-wise comparison of groups (t-tests). Only fish caught between 10:00 and 22:00 h were used in this analysis to control for observed diel differences in stomach fullness. Diel differences in stomach fullness was assessed in Ciliata mustela and Gaidropsaurus mediterraneus which were caught in adequate numbers over $24 \mathrm{~h}$ during August 1985

\section{RESULTS}

Fifty-seven prey types were distinguished among stomachs of the 9 species of fish studied. Copepod eggs contributed $70 \%$ of the total number of prey items taken by Ciliata septentrionalis ( $17 \%$ of fish), $63 \%$ by Ciliata mustela (19\% of fish), $68 \%$ by Ciliata spp. ( $47 \%$ of fish) and $14 \%$ by Pollachius pollachius $15.3 \%$ of fish). Up to 600 copepod eggs were counted in fish caught during May at Stns 15 and 16 (Fig. 1). These eggs were intact in the intestine and were not digested. They have been omitted from calculations of \% composition and \% occurrence data and when assessing the average number of prey eaten by groups of fish as they occurred in few fish and their inclusion in percentage composition data obscures the importance of other prey types (Table 2). C. septentrionalis and C. mustela preyed extensively on fish eggs, calanoid copepods, harpacticoid copepods and adult Calanus spp. Gaidropsaurus mediterraneus and Rhinonemus cimbrius fed mainly on copepods and cladocera. Crab megalopae, harpacticoid copepods, Calanus spp., Idotea spp. and Gammaridea (predominantly Gammarus locusta L.) were the dominant prey categories taken by Cyclopterus lumpus. Scophthalmus maximus specialised on Podon spp., Oikopleura spp. copepods and fish larvae. Pollachius virens ate mainly Calanus spp., Acartia spp. and fish eggs. The important prey categories of Pollachius pollachius were Acartia spp. and Calanus spp. while Merlangius merlangus preyed almost totally on copepods.

Prey categories contributing most to differences among $5 \mathrm{~mm}$ length groups of fish, isolated by stepwise discriminant analysis, are given in Table 3 for the spring group of fish and in Table 4 for the autumn group. Overall only $18.2 \%$ and $25.6 \%$ of autumn and spring groups respectively were correctly classified in the analysis, reflecting considerable dietary overlap among $5 \mathrm{~mm}$ length groups. Percentage occurrence
Table 3. Coefficients on canonical variables 1 to 4 , derived from step-wise discriminant analysis, of 17 prey categories, arranged in order of discriminating power, that best describe significant differences between the diets of $5 \mathrm{~mm}$ length groups of Ciliata septentrionalis, C. mustela, Pollachius pollachius and Merlangius merlangus

\begin{tabular}{|lrrrr|}
\hline & \multicolumn{5}{c|}{ Canonical variable } \\
Prey category & 1 & 2 & 3 & 4 \\
\hline & & & & \\
Acartia spp. & -1.02 & 2.21 & -0.05 & 1.11 \\
Fish eggs & 0.93 & -1.04 & 1.00 & 0.94 \\
Calanus spp. 1-1.5 mm & 2.01 & 0.86 & 0.82 & 1.22 \\
Copepod eggs & 0.20 & -0.76 & -0.08 & 0.31 \\
Podon spp. & 3.83 & 0.19 & -4.10 & 0.47 \\
Crab megalopa & 5.83 & 1.68 & -3.15 & -2.44 \\
Fish 20-25 mm & 9.79 & 6.19 & 7.24 & -20.13 \\
Harpacticoidea & 1.65 & 0.71 & -1.85 & 0.73 \\
Porcellana zoea & 2.84 & 1.42 & 1.98 & -0.89 \\
Corycaeus spp. & -2.39 & 3.74 & -2.56 & 2.13 \\
Cladocera & 1.76 & -0.45 & -1.36 & 0.07 \\
A. patersoni & 5.72 & -0.74 & -5.88 & -3.50 \\
Copepods 0.4-0.6mm & -0.57 & -1.01 & -0.49 & -0.81 \\
Fish 10-15 mm & 6.56 & 1.67 & 8.58 & 1.71 \\
$\quad$ 5-10 mm & 4.89 & 1.52 & 2.77 & -2.79 \\
Centropages spp. & 0.56 & -0.51 & -0.81 & 2.09 \\
Insects & 3.16 & 0.24 & 4.60 & 3.08 \\
Variance explained & 39.7 & 22.7 & 12.9 & 7.8 \\
Eigenvalue & 0.87 & 0.49 & 0.28 & 0.17 \\
Canonical correlation & 0.68 & 0.57 & 0.47 & 0.38 \\
\hline
\end{tabular}

Table 4. Coefficients on canonical variables 1 to 3 , derived from step-wise discriminant analysis, of 5 prey categories, arranged in order of discriminating power, that best describe significant differences between the diets of $5 \mathrm{~mm}$ length groups of Gaidropsaurus mediterraneus, Rhinonemus cimbrius, Scophthalmus maximus and Cyclopterus lumpus

\begin{tabular}{|lccc|}
\hline \multirow{2}{*}{ Prey category } & \multicolumn{4}{c|}{ Canonical variable } \\
& 1 & 2 & 3 \\
\hline Crab megalopa & -9.34 & 0.62 & 3.07 \\
Idotea spp. & -11.87 & 1.01 & -0.55 \\
Fish 10-15 mm & -3.14 & -15.63 & 2.61 \\
Harpacticoidea & -1.04 & -2.01 & -3.25 \\
Podon spp. & 0.23 & -1.85 & 1.64 \\
Variance explained & 82.4 & 7.7 & 5.3 \\
Eigenvalue & 11.3 & 1.1 & 0.7 \\
Canonical correlation & 0.96 & 0.72 & 0.65 \\
\hline
\end{tabular}

and composition data for these groups can be found in Tully (1986). The main features were the greater intraspecific differences in diet among $5 \mathrm{~mm}$ length groups of Ciliata spp. than between species as their diets gradually changed with increasing size, and the separation of all Ciliata groups from other species (Fig. 2). The high level of predation on fish eggs by Ciliata spp. and on Acartia spp. by Pollachius spp. were quantitatively important differences in the diets of these 2 main groups and these 2 prey categories were the most 


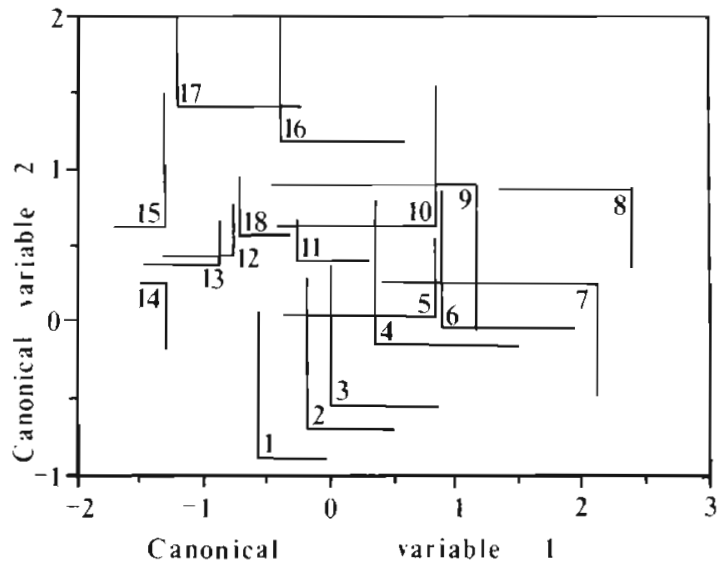

Fig. 2. Plot derived from step-wise discriminant analysis of the diets of $185 \mathrm{~mm}$ length groups of fish showing mean positions \pm standard deviation (horizontal and veritcal lines) on canonical variables 1 and 2. Key: Ciliata spp. 10-14 $\mathrm{mm}(1), C$. septentrionalis 14-19 $\mathrm{mm}(2), 19-24 \mathrm{~mm}$ (4), 24-29 $\mathrm{mm}(6)$, 29-34 mm (10), 34-39 mm (9), C. mustela 14-19 mm (3), 19-24 $\mathrm{mm}(5), 24-29 \mathrm{~mm}(7), 29-34 \mathrm{~mm}$ (8), Pollachius pollachius 5-10 mm (14), 10-15 mm (15), 15-20 mm (17), 20-25 mm (16), $P$. virens $20-25 \mathrm{~mm}(11), 25-29 \mathrm{~mm}$ (13), Merlangius merlangus 15-20 (12), 20-25 mm (18)

significant discriminating prey categories (Table 3). Discriminating variables with positive loadings on the first 2 canonical variables, mainly fish larvae Anomalocera patersoni, crab megalopae and insects (Table 3) are associated with Ciliata spp. over $25 \mathrm{~mm}$ length (Groups 7 to 10, Fig. 2) which also have positive loadings on both canonical variables. These prey were taken in greater numbers by these fish whereas fish eggs, small copepods and other negatively loaded prey categories on canonical variables 1 and 2 decreased in importance with increasing size. Pollachius pollachius, Pollachius virens and Merlangius merlangus groups are associated with variables, such as Acartia spp. and Corycaeus spp., which have negative loadings on canonical variable 1 and positive loadings on canonical variable 2 (Table 3, Fig. 2).

Five prey categories were significant in discriminating the diets of the autumn group of fish, compared with 17 for the spring group (Table 4). Although this may in part be due to the lower number of autumn fish examined it also reflects a specialisation by certain groups of Cyclopterus lumpus and Scophthalmus maximus on a few prey categories. Crab megalopae and Idotea spp. have high negative loadings on the first canonical variable (Table 4 ) and are associated with $C$. lumpus greater than $20 \mathrm{~mm}$ in length (Fig. 3). These 2 prey categories dominated the diet of these fish. $C$ lumpus less than $20 \mathrm{~mm}$ in length and harpacticoid copepods have low negative loadings on the first 2 canonical variables reflecting the greater importance of these copepods in small fish which took few megalopae or Idotea spp. The third discriminating variable, fish larvae and $S$. maximus (20 to $25 \mathrm{~mm}$ ) have high negative loadings on the second canonical variable (Table 4 , Fig. 3). This was the only group of autumn fish which preyed on fish larvae. Podon spp. the fifth discriminating variable, was dominant in the diet of smaller individuals of $S$. maximus and was also important in discriminating larger size groups of Gaidropsaurus mediterraneus and Rhinonemus cimbrius. Copepods dominated the diet of smaller fish of these 2 species. No significant differences in the levels of individual prey categories among length groups of these fish were found by discriminant analysis (Fig. 3).

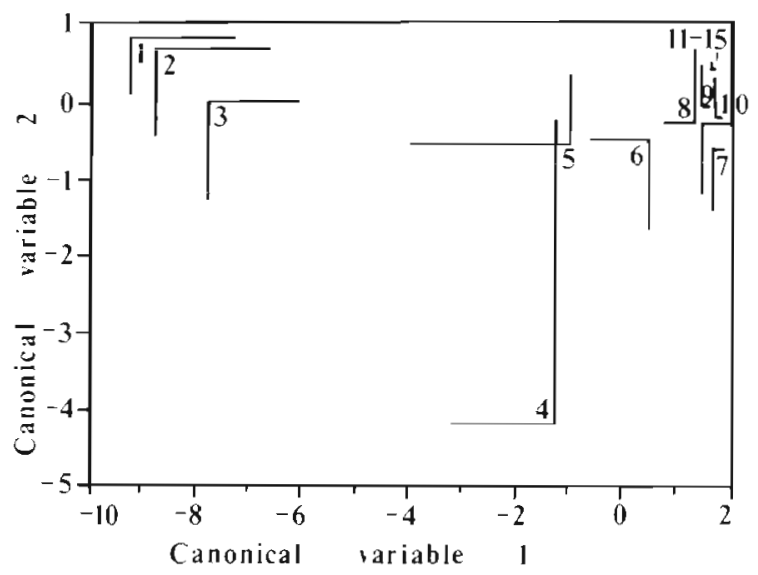

Fig. 3. Plot derived from step-wise discriminant analysis of the diets of $155 \mathrm{~mm}$ length groups of fish showing the mean positions \pm standard deviation (horizontal and vertical lines) on canonical variables 1 and 2. Key: Cyclopterus lumpus 10-15 mm (6), 15-20 mm (5), 20-25 mm (3), 25-30 mm (2), 30-35 mm (1). Scophthalmus maximus 10-15 $\mathrm{mm}$ (7), 20-25 $\mathrm{mm}$ (4), Gaidropsaurus mediterraneus 5-10 mm (14), 10-15 $\mathrm{mm}$ (11), 15-20 mm (15), 25-30 $\mathrm{mm}$ (9), 30-35 $\mathrm{mm}$ (8), Rhinonemus cimbrius $10-15 \mathrm{~mm}(13), 15-20 \mathrm{~mm}(12), 20-25$ $\mathrm{mm}(10)$

\section{Diel variation in food consumption}

Ciliata mustela and Gaidropsaurus mediterraneus caught over $24 \mathrm{~h}$ periods in September 1984 and August 1985 fed only during daylight hours. Stomach fullness increased throughout the day rising to a peak of over 4 (full) at 18:00 h. After sunset (ca 21:00 h) the index fell and was less than 1 at sunrise (06:00 h) (Fig. 4). Other indicators that feeding stopped after sunset were the partially digested state of stomach contents in fish caught after this time and the absence of vertically migrating benthic peracaridea in fish stomachs. These were the dominant species in neuston samples taken after sunset during August (Tully \& O Céidigh 1987) and were within the size range of prey taken by these fish. 
Fig. 4. Diel feeding pattern of Ciliata mustela (4-.-4) and Gaidropsaurus mediterraneus (-) during September 1985 and August 1985 combined. Vertical lines indicate standard deviations

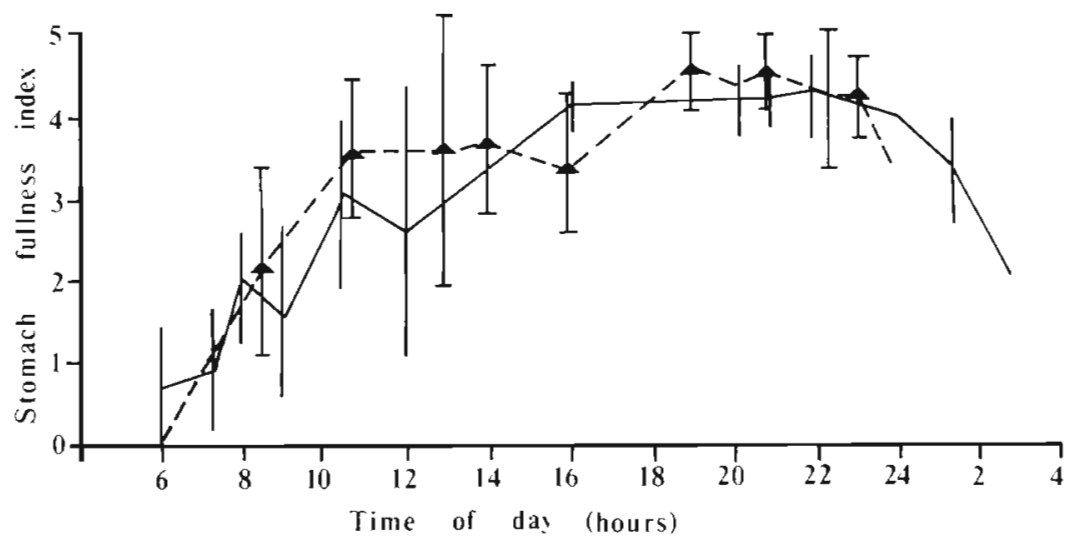

\section{Effects of fish species and fish length on food consumption}

In all species except Scophthalmus maximus and Gaidropsaurus mediterraneus the number of prey per fish was significantly different among $5 \mathrm{~mm}$ length groups, usually increasing with fish size (Table 5, Figs. 5 and 7). Among group differences in stomach fullness were insignificant in 5 species and significant in 4 species (Table 5, Figs. 6 and 8). In Pollachius pollachius stomach fullness and the number of prey eaten increased significantly between all except two $5 \mathrm{~mm}$ length groups in fish up to $25 \mathrm{~mm}$. In Ciliata mustela fish over $24 \mathrm{~mm}$ had fuller stomachs than Ciliata spp. 10 to $14 \mathrm{~mm}$ in length and there was also significant increases in the number of prey eaten by larger fish (Table5). Merlangius merlangus over $15 \mathrm{~mm}$ and Cyclopterus lumpus and Scophthalmus maximus over $20 \mathrm{~mm}$ also had fuller stomachs than smaller fish (Table5) although these increases were not always

Table 5. Variation in the number of prey per fish and stomach fullness among all and between individual pairs of $5 \mathrm{~mm}$ length groups of 9 species of fish. ${ }^{*} p<0.05, \cdots p<0.01, \cdots p<0.001$

\begin{tabular}{|c|c|c|c|c|c|c|}
\hline \multirow[t]{2}{*}{ Species } & \multicolumn{2}{|c|}{$\begin{array}{c}\text { Variation among groups } \\
\text { (F-statistic) }\end{array}$} & \multicolumn{2}{|c|}{$\begin{array}{c}\text { Pair-wise comparison } \\
\text { of groups }\end{array}$} & \multicolumn{2}{|c|}{ ( $t$-statistic) } \\
\hline & No. prey & Fullness & No. prey & Fullness & No. prey & Fullness \\
\hline C. septentrionalis & $5.19 \cdots$ & 1.31 & $\begin{array}{l}(10-14,24-29) \\
(10-14,29-34) \\
(14-19,24-29)\end{array}$ & & $\begin{array}{l}-4.57^{\circ} \\
-3.09^{\circ} \\
-3.34^{\circ}\end{array}$ & \\
\hline C. mustela & $16.12 \cdots$ & $8.79 \cdots$ & $\begin{array}{l}(10-14,14-19) \\
(10-14,19-24) \\
(10-14,19-24) \\
(10-14,29-34) \\
(14-19,24-29) \\
(19-24,24-29)\end{array}$ & $\begin{array}{l}(10-14,24-29) \\
(10-14,29-34)\end{array}$ & $\begin{array}{l}-3.36^{\circ} \\
-3.04^{\circ} \\
-7.21^{\cdots} \\
-4.11^{\cdots} \\
-4.19^{\cdots} \\
-3.51^{\cdots}\end{array}$ & $\begin{array}{l}-4.17^{\cdots} \\
-3.46^{\circ}\end{array}$ \\
\hline P. pollachius & $25.96 \cdots$ & $19.99 \cdots$ & $\begin{array}{l}(5-10,10-15) \\
(5-10,15-20) \\
(5-10,20-25) \\
(10-15,15-20) \\
(10-15,20-25) \\
(15-20,20-25)\end{array}$ & $\begin{array}{l}(5-10,15-20) \\
(5-10,20-25) \\
(10-15,15-20) \\
(10-15,20-25) \\
(15-20,20-25)\end{array}$ & $\begin{array}{l}-3.29^{\circ} \\
-7.73^{\cdots} \\
-8.45 \cdots \\
-4.68 \cdots \\
-6.20^{\cdots} \cdots \\
-2.76^{\circ}\end{array}$ & $\begin{array}{l}-3.90^{\cdots} \\
-5.56^{\cdots} \\
-4.66^{\cdots} \\
-6.46^{\cdots} \\
-2.95^{\circ}\end{array}$ \\
\hline P. virens & & & $(15-20,20-25)$ & & $-5.40^{\cdots}$ & \\
\hline M. merlangus & $5.19^{\mu}$ & $4.61^{\cdots}$ & $(10-15,15-20)$ & $(5-10,15-20)$ & $-2.99^{\circ}$ & $-3.38^{\circ}$ \\
\hline G. mediterraneus & 1.92 & 0.78 & $(5-10,15-20)$ & & $-3.65^{\circ}$ & \\
\hline R. cimbrius & $5.79^{\circ}$ & 0.56 & $(10-15,15-20)$ & & $-3.13^{\circ}$ & \\
\hline S. maximus & 1.99 & 3.23 & & $(10-20,20-25)$ & $-3.85^{\circ}$ & \\
\hline C. lumpus & $4.44^{\cdots}$ & $15.71 \cdots$ & $\begin{array}{l}(10-15,20-25) \\
(10-15,30-35)\end{array}$ & $\begin{array}{l}(10-15,20-25) \\
(10-15,25-30) \\
(10-15,30-35)\end{array}$ & $\begin{array}{l}-3.52^{\circ} \\
-3.35^{\circ}\end{array}$ & $\begin{array}{l}-5.09 \cdots \\
-5.53 \cdots \\
-7.18 \cdots\end{array}$ \\
\hline
\end{tabular}




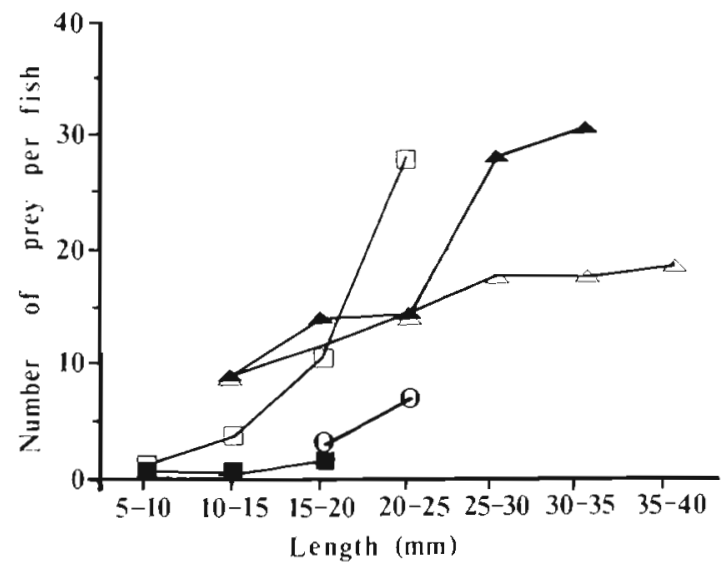

Fig. 5. Mean number of prey per fish for $5 \mathrm{~mm}$ length groups of Ciliata septentrionalis (A), C. mustela (A), Pollachius pollachius ( $\square$ ), $P$. virens (O) and Merlangius merlangus

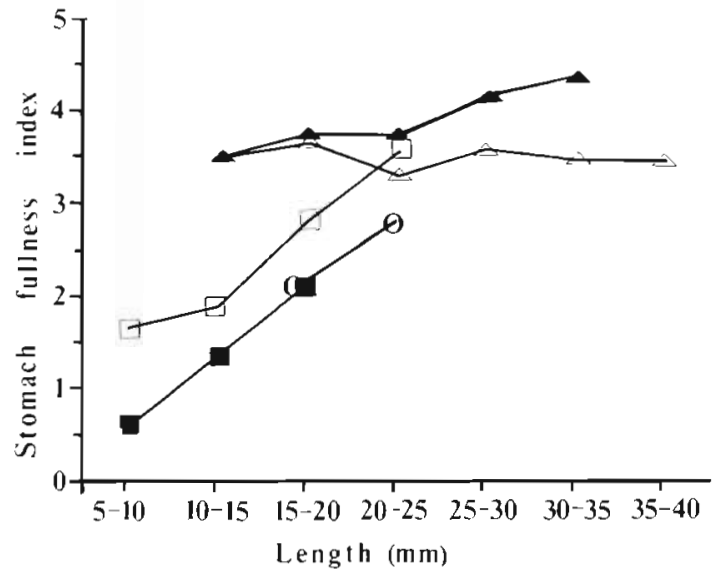

Fig. 6. Mean stomach fullness for $5 \mathrm{~mm}$ length groups of 5 species of fish. Key as in. Fig. 5

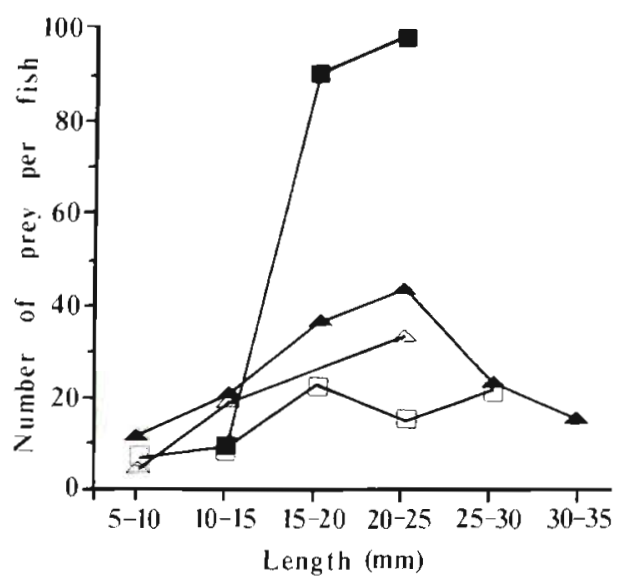

Fig. 7. Mean number of prey per fish for $5 \mathrm{~mm}$ length groups of Gaidropsaurus mediterraneus ( $\mathbf{-}$ ), Rhinonemus cimbrius ( $\mathbf{\square}$ ), Cyclopterus lumpus $(\square)$ and Scophthalmus maximus ( $\triangle$ )

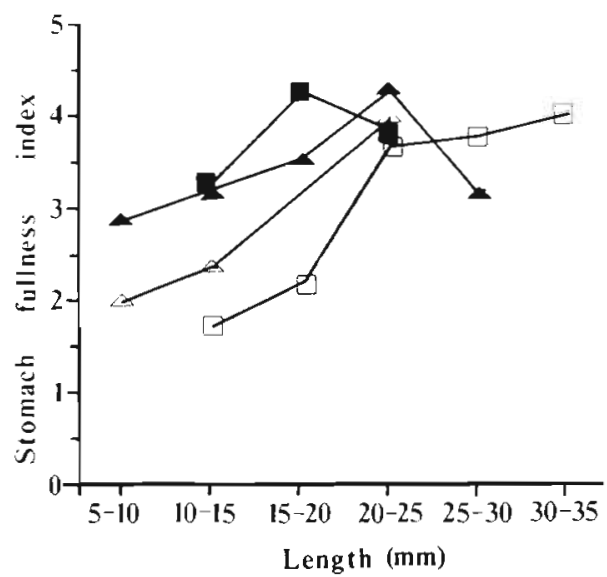

Fig. 8. Mean stomach fullness for $5 \mathrm{~mm}$ length groups of 4 species of fish. Key as in Fig. 7

accompanied by increases in the number of prey eaten. This is evidence of a switch to larger prey in bigger fish and occurred in C. lumpus and $S$. maximus (Table 5).

Mean stomach fullness in neustonic species was consistently over 3.5 in Ciliata septentrionalis and Ciliata mustela (Fig. 6) and over 3 in Gaudropsaurus mediterraneus and Rhinonemus cimbrius in all sizes of fish analysed (Fig. 8). The pseudoneustonic species Merlangius merlangus and Pollachius virens ate very low numbers of prey and never had stomachs that were over $1 / 3$ full (Figs. 5 and 6). Small individuals of Pollachius pollachius, Cyclopterus lumpus and Scophthalmus maximus also had comparatively low values on the fullness index (Figs. 6 and 8).

\section{DISCUSSION}

The number of prey options available to post-larval and juvenile fish is limited both by the size-frequency distribution of the potential prey population and by the number of potential prey species present since individual prey species are likely to have species-specific behaviours and distributions. The inability to identify certain prey items beyond a broad taxonomic level and the creation of arbitrary prey size classes of unidentified prey items that may not really represent different prey options for predators are limiting factors in the interindividual comparison of diets by multivariate statistical analysis. The number of variables (prey categories) used in such an analysis depends both on the prey size classes created and the level to which prey were identified.

Within these constraints the food of some species in the spring and autumn species groups were shown to be different as were the diets of smaller and larger fish of individual species. Features of the diets of Ciliata 
spp. were the numbers of fish eggs and copepod eggs eaten. Other post-larval and 0-group gadoids and neustonic rockling species recorded during autumn in the present work (Gaidropsaurus mediterraneus and Rhinonemus cimbrius) do not prey extensively on fish eggs (Last 1978, Conway 1980, Robb \& Hislop 1980 , Robb 1981, present data). Copepod eggs, which were eaten in large numbers by Ciliata spp. are unlikely to be optimal prey items for these fish because of their size $(150 \mu \mathrm{m})$ and because they are resistant to digestion. Undigested copepod eggs were also recorded in Mugil spp. by Zismann et al. (1975) and in Micromesistius poutassou (Risso) by Conway (1980). The diet of Scophthalmus maximus in Galway Bay and that described for the species in the North Sea by Last (1978) were broadly similar. Differences included the absence of fish larvae and the presence of fish eggs in North Sea specimens and the predation on Oikopleura spp. by larvae under $11 \mathrm{~mm}$ in the North Sea but mainly by fish over $15 \mathrm{~mm}$ in Galway Bay. The diet of $S$. maximus, which was the only flatfish (family Bothidae) species studied, was very different to that of others. The food of Cyclopterus lumpus was also distinct and was made up mostly of crustaceans which, like C. lumpus, associate with driftweed, i.e. Idotea spp., Gammarus locusta L. (Tully \& O Céidigh 1986) and harpacticoid copepods. The high degree of prey selectivity shown by $C$. lumpus and $S$. maximus, the different size, quality and quantity of food eaten by different sized fish, the high level of food consumption by neustonic species and the high density of juvenile fish in the neustal during daylight hours all indicate that an adequate food supply was available to the size range of fish studied. The degree to which copepod eggs were taken at stations outside of Galway Bay however, may indicate that in some instances food was scarce.

Two trends in dietary shift as fish increased in size were obvious. The diets of Cyclopterus lumpus and Scophthalmus maximus changed abruptly as fish length increased. These abrupt changes in the diets of these 2 species, which were accompanied by significant increases in stomach fullness but insignificant increases in the number of prey eaten by larger fish (i.e. a switch to larger and different species of prey), are evidence of different feeding stanzas (Paloheimo \& Dickie 1965) or trophic groups within the length range of fish examined for these species. Using such changes in prey categories and sizes eaten as criteria for determining the existence of feeding stanzas only one trophic group was recognisable in other species as their diets changed only gradually with fish size. This gradual change in diet was also reported by Robb \& Hislop (1980) for 0-group gadoids in the North Sea. However, larger individuals of Ciliata mustela, Pollachius pollachius and Merlangius merlangus ate significantly higher numbers of prey and had significantly fuller stomachs. This increase in the number of prey eaten by larger fish is an alternative strategy to switching to larger prey. When accompanied by a significant increase in stomach fullness it is evidence of an increase in food consumption by larger fish above that expected simply from the increase in fish size (i.e. a greater amount of food consumed per unit size of fish). Shifts in the prey categories taken by these species as fish increased in length did occur simultaneously with this increase in stomach fullness. Tropho-dynamically speaking these groups of larger fish can be seen as belonging to a different trophic group also because, in proportion to fish size, their impact on the prey population is greater than that of smaller fish.

A comparison of the average stomach fullness of neustonic rockling species Ciliata septentrionalis, Ciliata mustela, Rhinonemus cimbrius and Gaidropsaurus mediterraneus between 10 and $25 \mathrm{~mm}$ in length with other gadoid species of similar length which were pseudoneustonic, i.e. Pollachius pollachius, Pollachius virens and Merlangius merlangus, showed that the neustonic species and P. pollachius over $20 \mathrm{~mm}$ had fuller stomachs than pseudoneustonic species. Rockling had consistently high values on the index regardless of fish length. Significant increases with length were evident only between 3 groups of $C$. mustela. Neustonic species, therefore, seemingly fed more successfully in the neustal than pseudoneustonic individuals. This may infer that feeding conditions at the sea surface are different to those of deeper water and that neustonic species have adaptations that enable them to cope with this environment more successfully than other species. Whether $M$. merlangus and $P$. virens feed more intensively in deeper water was not assessed. However, $M$. merlangus caught in a pelagic trawl in the North Sea by Robb \& Hislop (1980) consumed a far greater number of prey than specimens caught in the neustal of Galway Bay.

Acknowledgements. David Burke, Eoin McLoughlin, Padraic Casey, Marcus Hernon and the crew of the RV 'Lough Beltra' all participated in field work.

\section{LITERATURE CITED}

Berthois, L., Auffret, G. A., Du Buit, M. H., Keary, R. (1971). Contribution à l'étude de l'hydrologie et de la sedimentation dans la baie de Galway (Eire). Ann. Inst. océanogr., Paris XLVIII (1): $17-48$

Booth, D. A. (1975). The water structure and circulation of Killary Harbour and of Galway Bay. M. Sc. thesis, National University of Ireland

Champalbert, G. (1971a). Variations nycthemerales du plancton superficiel. 1. Holohyponeuston et heterohyponeuston. J. exp. mar. Biol. Ecol. 6: 23-33

Champalbert, G. (1971b). Variations nycthemerales du planc- 
ton superficiel. II. Espèces non caracteristique de l'hyponeuston et hyponeuston nocturne. J. exp. mar Biol Ecol. 6: 55-70

Champalbert, G., Macquart-Moulin, C. (1970). Les paracarides de l'hyponeuston nocturne du Golfe de Marseille. Cah. Biol. mar XI: 1-29

Conway, D. V. P. (1980). The food of larval blue whiting, Micromesistius poutassou (Risso) in the Rockall area. J. Fish. Biol. 16: 709-723

Fives, J. M. (1969). Investigations of the plankton of the west coast of Ireland. II. Planktonic copepods taken off Co. Galway and adjacent areas in plankton surveys during the years 1959-1963. Proc. R. Ir. Acad. 67B, 10: 233-259

Fives, J. M. (1970). Investigations of the plankton of the west coast of Ireland. IV Larval and post-larval stages of fishes taken from the plankton of the west coast during the years 1958-1966. Proc. R. Ir. Acad. 70B, 3: 15-93

Fives, J. M. (1971). Investigations of the plankton of the west coast of Ireland. V. Chaetognatha recorded from the inshore plankton of Co. Galway. Proc. R. Ir. Acad. 71B, 9: 119-138

Hartman, J. (1970). Verteilung und Nährung des Ichthyoneuston im subtropischen Nordostatlantik. 'Meteor' Forsch.Ergebn. D 8: 1-60

Hempel, G., Weikert, H. (1972). The neuston of the subtropical and boreal Northeastern Atlantic ocean. A review. Mar Biol. 13: 70-88

Jennrich, R., Sampson, P. (1981). Stepwise discriminant analysis. In: Dixon, W. J. (chief ed.) Biomedical data processing, 2nd edn. University of California press, Los Angeles, p. $519-537$

John, H.-Chr. (1973). Oberflächennahes Ichthyoplankton der Kanarenstrom-Region. 'Meteor' Forsch.-Ergebn. D 15: $36-50$

Last, J. M. (1978). The food of three species of gadoid larvae in the eastern English Channel and souther North Sea. Mar. Biol. 48: 377-386
Macquart-Moulin, C. (1984). La phase pelagique nocturne et comportements migratoires des Amphipodes benthiques (Mediterranée, Nord-Occidentale). Téthys 11 (2): 171-196

$O$ Céidigh, P. (1962). The marine Decapoda of the counties Galway and Clare. Proc. R. Ir. Acad. 62B, 11: 151-174

Paloheimo, J. E., Dickie, L. M. (1965). Food and growth of fishes. J. Fish. Res. Bd Can. 22: 521-542

Robb, A. P. (1981). Observations on the food and diel feeding behaviour of pelagic 0 -group gadoids in the northern North Sea. J. Fish. Biol. 18: 183-194

Robb, A. P., Hislop, J. R. G. (1980). The food of tive gadoid species during the pelagic 0-group phase in the northern North Sea. J. Fish. Biol. 16: 199-217

Tully, O. (1986). The benthohyponeuston and ichthyoneuston of Galway Bay. Ph. D. thesis, National University of Ireland

Tully, O., O Céidigh. P. (1986a). The ecology of Idotea spp. (Isopoda) and Gammarus locusta (Amphipoda) on surface driftweed in Galway Bay (west of Ireland). J. mar. biol. Ass. U.K. 66: 931-942

Tully, O., O Céidigh, P. (1986b). Density variations and population structure of Eurydice inermis and E. truncata (Isopoda: Cirolanidae) in the neuston of Galway Bay (Ireland). Cah. Biol. mar XXVII: 225-233

Tully, $0 ., O$ Ceidigh, P. (1987). Investigations of the plankton of the west coast of Ireland - VIII. The neustonic phase and vertical migratory behaviour of benthic peracaridea in Galway Bay. Proc. R. Ir. Acad. 87B, 3: 43-64

Tully, O., O Céidigh, P. (1988). The ichthyoneuston of Galway Bay. 1 The seasonal, diel and spatial distribution of postlarval and juvenile fish. Mar. Biol. (in press)

Zaitsev, Yu. P. (1970). Marine neustonology. Naukova Dumka, Kiev. Translated from Russian by IPST Jerusalem 1971

Zismann, L., Berdugo, V., Kimor, B. (1975). The food and feeding habits of early stages of grey mullets in the Haifa Bay region. Aquaculture 6: 59-75 